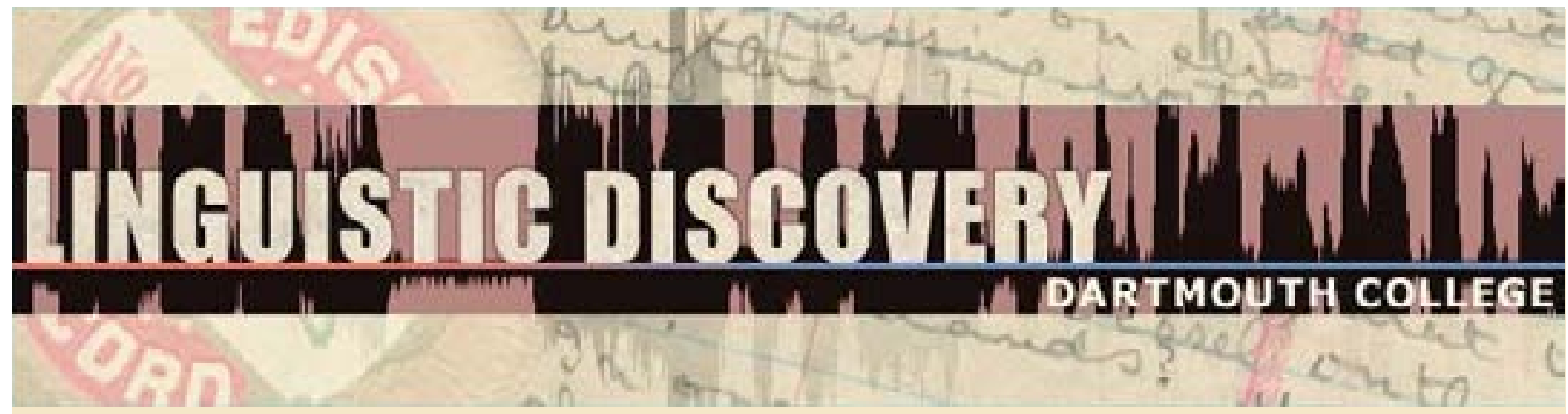

Volume 8 Issue 1 2010

\section{Introduction to the Special Issue: "Semantic Maps: Methods and Applications"}

Michael Cysouw, Martin Haspelmath, Andrej Malchukov

Max Planck Institute for Evolutionary Anthropology, Leipzig

doi: 10.1349/PS1.1537-0852.A.358

url: http://journals.dartmouth.edu/cgi-bin/WebObjects/ Journals.woa/1/xmlpage/1/article/358 


\section{Introduction to the Special Issue "Semantic Maps: Methods and Applications"}

Michael Cysouw, Martin Haspelmath, Andrej Malchukov

Max Planck Institute for Evolutionary Anthropology, Leipzig

In recent years the semantic map methodology has enjoyed increasing popularity in cross-linguistic studies. Although there are various ways to create semantic maps, they are all attempts to visually represent cross-linguistic regularity in semantic structure. It has become increasingly clear that these attempts to map out linguistic categorization provide an empirically testable tool for the study of semantic variation across languages. Furthermore, the semantic map approach has shown convergence with grammaticalization theory as well as with research using (implicational) hierarchies, as found in functional typology and optimality theory.

Early approaches to drawing semantic maps can be found in Hjelmslev (1963: 53, discussed by Haspelmath 2003: 237), Lazard (2001[1981]: 54), and Anderson (1982). In recent years, semantic maps have been proposed for diverse aspects of linguistic structure, including tense/aspect (e.g., Anderson 1982; Janda. 2007; Croft \& Poole 2008), modality (Anderson 1986; Van der Auwera \& Plungian 1998), voice (Kemmer 1993; Croft 2001), pronouns (Haspelmath 1997a; Cysouw 2007), case-marking (Haspelmath 2003; Narrog \& Ito 2007; Rice \& Kabata 2007), clause linkage (Kortmann 1997; Malchukov 2004), spatial and temporal domain (Haspelmath 1997b; Levinson \& Meira 2003), as well as for a number of syntactic domains, such as intransitive predication (Stassen 1997) and secondary predication (Van der Auwera \& Malchukov 2005). Recently, the issue of applying semantic maps to lexical typology-as anticipated already in the early studies by Hjelmslev and Lazard - has also been taken up by Majid et. al. (2008) and François (2008).

The papers in this special issue of Linguistic Discovery are a selection of the presentations given at a workshop on semantic maps held adjacent to the seventh meeting of the Association of Linguistic Typology (ALT 7) on 29 September 2007 in Villejuif near Paris. This workshop invited contributions related to the further understanding of the semantic map method, dealing with topics such as:

- Status of semantic maps in linguistic theory

- Methods of building semantic maps from data

- Limits of the semantic map approach

- Possibilities for and problems with the interpretation of semantic maps

- Relation between semantic maps and grammaticalization chains

- Presentation and discussion of particular semantic maps

- Scalability of the method to build semantic maps

- Implications of cross-linguistically rare phenomena for semantic maps

The goal of the workshop was to address these topics in order to contribute, both empirically and theoretically, to the development of the semantic map methodology. As it turned out, the major emphasis of many presentations at the workshop (likewise permeating almost all papers in this volume) was the discussion between the "classical" graph-based approach to drawing semantic maps and the more recent approaches using a distance-based metaphor for the depiction. Some general discussion and references on the received graph-based method of building semantic maps can be found in Croft (2001) and Haspelmath (2003). Some first attempts to use distance-based statistical techniques to draw semantic maps (especially multidimensional scaling) can be found in Cysouw (2001), Levinson \& Meira (2003), and especially in Croft \& 
Poole (published in 2008 but in circulation as a manuscript since 2004).

Croft \& Poole's paper appeared as a position paper in Theoretical Linguistics (issue 34/1 of 2008) supplemented with peer commentary and an authors' reply. In terms of organization and presentation, that journal issue is closely related to the present collection of papers and can perhaps be read as a companion volume. In our collection, too, the final drafts of the papers were circulated among the authors (as well as the typological community in general) to attract critical commentary. Within a rather restricted time-frame, we received comments for almost all papers (and even more than one comment for a few papers). The authors were then given the opportunity to write a reply to these comments. The resulting miniature discussion is published alongside the original paper in this special issue. All comments and replies have been formally conceived as separate publications (formally referencing the paper on which they comment or reply) so they can be easily cited independently of the original paper.

\section{References}

Anderson, Lloyd B. 1982. The 'perfect' as a universal and as a language-particular category. Tense-Aspect: Between Semantics \& Pragmatics, ed. by Paul J. Hopper, 227-264. Amsterdam: Benjamins.

-----. 1986. Evidentials, paths of change, and mental maps: typologically regular asymmetries. Evidentiality: The linguistic encoding of epistemology, ed. by. Wallace Chafe \& Johanna Nichols, 273-312. Norwood: Ablex.

Croft, William. 2001. Radical construction grammar. Oxford: Oxford University Press.

Croft, William \& Keith T. Poole. 2008. Inferring universals from grammatical variation: Multidimensional scaling for typological analysis. Theoretical Linguistics 34/1.1-38.

Cysouw, Michael. 2001. Review of 'Indefinite Pronouns' by Martin Haspelmath, Journal of Linguistics 37/3.99-114.

-----. 2007. Building semantic maps: the case of person marking. New Challenges in Typology, ed. by Bernhard Wälchli \& Matti Miestamo, 225-248. Berlin: Mouton.

François, Alexandre. 2008. Semantic maps and the typology of colexification: Intertwining polysemous networks across languages. From polysemy to semantic change: towards a typology of lexical semantic associations, ed. by Martine Vanhove, 163-215. Amsterdam: Benjamins.

Haspelmath, Martin. 1997a. Indefinite Pronouns. Oxford: Clarendon.

-----. 1997b. From space to time: temporal adverbials in the world's languages. München: Lincom.

-----. 2003. The geometry of grammatical meaning: semantic maps and cross-linguistic comparison. The new psychology of language, vol. 2, ed. by M. Tomasello, 211-243. New York: Erlbaum.

Hjelmslev, Louis. 1963. Prolegomena to a theory of language. Madison: The University of Wisconsin Press.

Janda, Laura. 2007. Aspectual clusters of Russian verbs. Studies in Language 31/3.607-648.

Kemmer, Susan. 1993. The middle voice. Amsterdam: Benjamins.

Kortmann, Bernd. 1997. Adverbial subordination: a typology and history of adverbial subordinators based on European languages. Berlin: Mouton.

Lazard, Gilbert 2001[1981]. La quête des universaux sémantiques en linguistique. Études de Linguistique Générale, 47-56. Peeters: Leuven. (reprint from Actes sémiotiques-Bulletin 19.26-37).

Levinson, Stephen \& Sergio Meira. 2003. 'Natural concepts' in the spatial topological domain - 
Adpositional meanings in crosslinguistic perspective: An exercise in semantic typology. Language 79/3.485-516.

Malchukov, Andrej. 2004. Towards a semantic typology of adversative and contrast marking. Journal of semantics, 21/2.177-198.

Majid, A., Boster, J. S., \& Bowerman, M. (2008). The cross-linguistic categorization of everyday events: A study of cutting and breaking. Cognition, 109/2.235-250.

Narrog, Heiko, and Ito Shinya. 2007. Re-constructing semantic maps: the Comitative-Instrumental area, Sprachtypologie und Universalienforschung, 60/4.273-292.

Rice, S. \& K. Kabata 2007. Crosslinguistic grammaticalization patterns of the ALLATIVE. Linguistic Typology 11/3.451-514

Stassen, Leon 1997. Intransitive predication: an essay in linguistic typology. Oxford: Oxford University press.

Van der Auwera, Johan \& Malchukov, Andrej 2005. A semantic map for depictive adjectivals. Secondary predication and adverbial modification. The typology of depictive constructions, ed. by Nikolaus P. Himmelmann \& Eva Schultze-Berndt, 393-423. Oxford: Oxford University Press.

Van der Auwera, Johan \& Plungian, V.A. 1998. Modality's semantic map. Linguistic Typology, 2/1.79-124. 